\title{
Soil erodibility calculations based on different particle size distribution measurements
}

\author{
Csaba CENTERI ${ }^{1}$, Zoltán SZALAI ${ }^{2}$, Gergely JAKAB², Károly BARTA³ \\ ANDREA FARSANG ${ }^{3}$, SZILÁRd SZABÓ ${ }^{4}$ and Zsolt BÍRÓ 5
}

\begin{abstract}
In this study we focused on the factors affecting final outputs of the USLE (Universal Soil Loss Equation) model. In doing so, we conducted soil particle size measurements in different institutions (University of Debrecen, University of Szeged and Geographical Institute, Research Centre for Astronomy and Earth Sciences of the Hungarian Academy of Sciences) with a variety of methodologies (laser, aerometer and pipette methods) on various soil materials (sandy, loamy and clay). Statistical analyses of the eight examined soil samples have been shown some significant and some non-significant differences among the particle size measurements. This paper is aimed at i) to ascertain whether these significant differences in particle size measurements cause significant differences in soil erodibility calculations; and ii) to assess the amount of soil loss calculated by these $\mathrm{K}$ factors. The results suggest that regardless of the relatively small percentage between the smallest and the greatest $\mathrm{K}$ factor values, the amount of soil loss can be fairly high, especially when erosion occurs on a longer or steeper slope. In the present case, when we compare simulations results, the amount of soil loss is more important than the difference in percentage between the minimum and maximum values. Because the percentage of the difference can remain the same between the simulations, while the amount of soil loss increases way beyond soil loss tolerance limits.
\end{abstract}

Keywords: methods of particle size measurement, soil erodibility, USLE

\section{Introduction}

There has been a great deal of discussion about soils and their role in food production. Perhaps most importantly, soil is the main natural element from where the majority of the food for the human population originates. This topic becomes especially prescient because numerous scientists have declared that soil is a finite resource (ÁNGYÁN,

\footnotetext{
${ }^{1}$ Department of Nature Conservation and Landscape Ecology, Institute of Environmental and Landscape Management, Szent István University, H-2100 Gödöllő, Páter K. u. 1. E-mail: centeri.csaba@kti.szie.hu

${ }^{2}$ Geographical Institute, Research Centre for Astronomy and Earth Sciences, HAS, H-1112 Budapest, Budaörsi út 45. E-mails: szalai.zoltan@csfk.mta.hu, jakab.gergely@csfk.mta.hu

${ }^{3}$ Department of Physical Geography and Geoinfor-matics, University of Szeged, H-6720 Szeged, Egyetem u. 2. E-mails: farsang@geo.u-szeged.hu,barta@geo.u-szeged.hu

${ }^{4}$ Department of Physical Geography and Geoinfor-mation Systems, Debrecen University, H-4032 Debrecen, Egyetem tér 1. E-mail: szabo.szilard@science.unideb.hu

${ }^{5}$ Institute for Wildlife Conservation, Szent István University, H-2100, Gödöllő, Páter K. u. 1.

E-mail: bzsolti@ns.vvt.gau.hu
} 
J. 2001; Centeri, Cs. 2002; Centeri, Cs. et al. 2009, 2011, 2012; Madarász, B. et al. 2012). Therefore, understanding soil erosion in a more efficient and comprehensive way has a furthermost importance.

Soil stands in the focal point of soil erosion researches whose aims are primarily to protect this valuable resource (KERTÉsz, Á. 1993; SzIlassi, P. et al. 2006; BÁdONYI, K. et al. 2008; Barczi, A. and Joó, K. 2009; Madarász, B. et al. 2011). When we are examining soil, it is done so from various points of view (Merinó, A. et al. 2004; BArCZI, A. et al. 2009; Petó, Á. 2011; Fonseca, F. et al. 2012; Petô, Á. 2013; Kondrlová, E. et al. 2013). Soil erosion modelling is a useful tool for predicting potential amounts of soil loss (RojAs, R. et al. 2008; Heng, B.C.P. et al. 2011; Pradhan, B. et al. 2011). Soil erosion models must be examined in situ to obtain as much appropriate data as possible (Centeri, Cs. 2002; Centeri, Cs. et. al. 2009, 2011, 2012). Any additional data and research related to the increase of reliability of the models are most welcomed by model users (Madarász, B. et al. 2012). Soil particle size distribution is measured by various authors for various purposes ( $\mathrm{Su}$, Y.Z. et al. 2004). In the present case, the soil erodibility factor is analysed based on the liability of measuring an important input parameter, namely, the particle size distribution.

In the field of soil science, there has recently been a growing number of physically-based soil erosion models created and their application is rapidly increasing. As the input need of such physical models is much larger than those of the empirical models, any research investigating the reliability of factors affecting the final outputs of a model is valuable.

This research illustrates many effects of particle size measurements methods on soil erodibility factors of the USLE (Universal Soil Loss Equation) model. As particle size distribution is an important parameter for all other soil erosion models, these data can be used for other models as well (GiovanNinI, G. 2001).

\section{Data and methods}

Eight soil samples were chosen from seven different Hungarian locations of various soils (Figure 1). The samples represent a wide palette of soil textures and soil structures. In some cases there were no significant aggregating effects among the coarse particles. Other samples had higher clay contents with additional inorganic and humus colloids that resulted in more resistant aggregates (i.e. samples from the BOR, GFH and GAH).

Three institutions participated in the measurements and three methods were used. The codification of all information and basic geographical and other relevant parameters of the environment of the sample sites are available in Table 1.

Table 1. Codification of samples, sample sites and participating institutes

\begin{tabular}{|c|c|}
\hline Code & Name of the participating institute \\
\hline $\begin{array}{l}\text { S } \\
\text { D } \\
\text { F }\end{array}$ & $\begin{array}{l}\text { University of Szeged } \\
\text { University of Debrecen } \\
\text { Geographical Institute, RCAES HAS }\end{array}$ \\
\hline Code & Sample site information \\
\hline $\begin{array}{l}\text { BOR } \\
\text { GAH } \\
\text { GFH } \\
\text { SZG } \\
\text { TUR } \\
\text { KMA } \\
\text { FES } \\
\text { GAL }\end{array}$ & $\begin{array}{l}\text { Börzsöny Mountains, mountain top } \\
\text { Gyöngyöstarján (Mátra Mountains) } \\
\text { Gyöngyöstarján (Mátra Mountains) } \\
\text { Szentgyörgyvár (Zala Hills) } \\
\text { Tura (Lowlands of Hatvan) } \\
\text { Kiskunmajsa (sandy lowland) } \\
\text { Dabas (sandy lowland) } \\
\text { Galgahévíz (Lowlands of Hatvan) }\end{array}$ \\
\hline Code & Method of measurement \\
\hline $\begin{array}{l}\text { A } \\
\text { L } \\
\text { P } \\
\text { P1 } \\
\text { P2 }\end{array}$ & $\begin{array}{l}\text { Areometer } \\
\text { Laser method } \\
\text { Pipette method } \\
\text { Pipette method, laboratory staff No. 1. (D) } \\
\text { Pipette method, laboratory staff No. 2. (D) }\end{array}$ \\
\hline Code & Replicates \\
\hline $\begin{array}{l}1 \\
2 \\
\end{array}$ & $\begin{array}{l}\text { Replicate } 1 \\
\text { Replicate } 2\end{array}$ \\
\hline
\end{tabular}

Measurements with the Laser Particle Sizer Analysette 22 MicroTech method

Sample preparation was carried out without OM (organic matter) takeout using sodium 


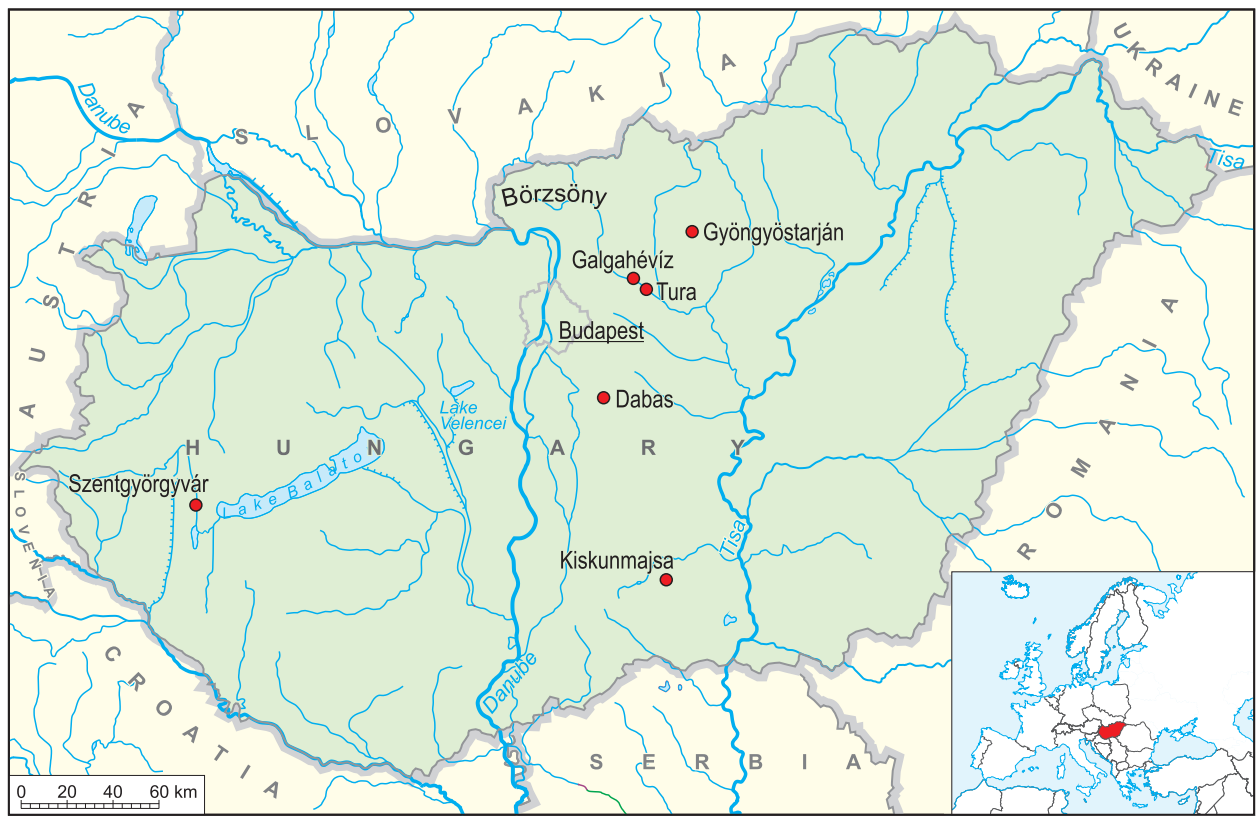

Fig. 1. Origin of the eight soil samples from seven locations, in Hungary

pyrophosphate in order to disperse the aggregates into elemental particles. $20 \mathrm{~g}$ of air dried soil was dispersed in $25 \mathrm{ml}(0.5 \mathrm{n})$ sodium pyrophosphate for 24 hours.

The suspension was leached through a 500 $\mu \mathrm{m}$ sieve and measured in a diffractometer Laser Particle Sizer Analysette 22 (Fritsch $\mathrm{GmbH}$ Germany). The measuring range of the used unit (MicroTec) was 0.1-670 $\mu \mathrm{m}$. The coarse fractions $(>500 \mu \mathrm{m})$ were determined by sieving. The measuring unit of "Analysette 22" contains a helium-neon laser below $5 \mathrm{~mW}$ and a wavelength of $655 \mathrm{~nm}$. A Fourier lens then gathered the diffracted beams onto the detector.

The apparatus uses the Mie-theory (Mie, G. 1908) to calculate grain-sizes from the intensity of the diffracted laser light. The results were classified into 102 size classes. One measurement was an average of 180 scans of the sample therefore no repetitions were applied.
Determination of particle size distribution with the Köhn-pipette method

Measurements were carried out according to BuzÁs, I. (1993), using the Hungarian patent of particle size distribution (MSZ-08-02051978). The method needs soil sample preparation (i.e. organic matter removed with $\mathrm{H}_{2} \mathrm{O}_{2}$, sieved with $\varnothing=0.2 \mathrm{~mm}$ mesh size). A mortar was applied with water and continuous rubbing.

The finest fractions were poured into a sedimentation vessel. This procedure was repeated until there were no fine particles in the mortar in which the whole sample was then washed into the vessel.

The suspension was filled up to $1,000 \mathrm{ml}$ with distilled water and $10 \mathrm{ml} 0.2 \mathrm{M}$ sodium-oxalate was added to prevent coagulation. The settling time was calculated at 10 $\mathrm{cm}$ below the surface. Finally, after the finest $(<0.001 \mathrm{~mm})$ fraction had settled, the pipetted 
samples were dried at $105{ }^{\circ} \mathrm{C}$ to determine their weight. Soils' particle size classes were expressed in percentage.

Determination of particle size distribution with the Aerometer method

This method is based on Stokes' law. Suspension is made from a $20-60 \mathrm{~g}$ sample. The moisture of the original sample is determined with gravimetry. To prevent coagulation, $0.5-1 \mathrm{~g}$ sodium-pyrophosphate is added to the suspension and then it is filled to $1,000 \mathrm{~cm}^{3}$ with distilled water. The density of soil suspension measured at $30 \mathrm{~s}$ intervals for 24 hours by an aerometer (MSZ 14043/3: 1979; BuzÁs, I. 1993).

\section{Calculation of soil erodibility values}

Soil erodibility has been calculated with the following equation according to SCHWERTMANN, U. et al. (1987):

$$
\begin{gathered}
K=2.77 \cdot M^{1.14} \cdot 10^{-6} \cdot(12-O S)+0.043 \cdot(A-2)+ \\
+0.033 \cdot(4-D)
\end{gathered}
$$

where $M=$ (particle fraction between 0.063 $\mathrm{mm}$ and $0.002 \mathrm{~mm}[\%]+$ particle fraction between $0.1 \mathrm{~mm}$ and $0.063 \mathrm{~mm}[\%]) \times($ particle fraction between $0.063 \mathrm{~mm}$ and $0.002 \mathrm{~mm}$
[\%] + particle fraction between $2.0 \mathrm{~mm}$ and $0.063 \mathrm{~mm}[\%])$ OS is the percentage content of organic substance (if $O S>4 \%, O S=4 \%$ ); $A$ = aggregate category; $D=$ category of permeability. In this case, $A=2$ (soil aggregates are between 1-2 $\mathrm{mm}$ ) and $D=3$ (infiltration rate is between 10-40 $\mathrm{cm} \cdot$ day $^{-1}$ ) (SchwertmanN, U. et al. 1987).

Parametrization of the USLE model

We used USLE model to check whether the soil erodibility values calculated with the measured particle size distributions in different institutions with different methodologies have an effect on the amount of soil loss. The following parameters were in the calculation: $R$ factor $=1,300\left(\mathrm{MJ} \mathrm{mm} \mathrm{ha}{ }^{-1} \mathrm{~h}^{-1} \mathrm{y}^{-1}\right), L S=3.5$, $C=0.5$ and $P=1$.

\section{Research findings}

Results of $K$ factor calculations with USLE methodology based on the particle size distribution measurements from 3 institutions (University of Debrecen, University of Szeged and Geographical Institute, Research Centre for Astronomy and Earth Sciences of the Hungarian Academy of Sciences), using 3 methods (laser, pipette and aerometer). The resulting $K$ factor calculations are shown in Figure 2.

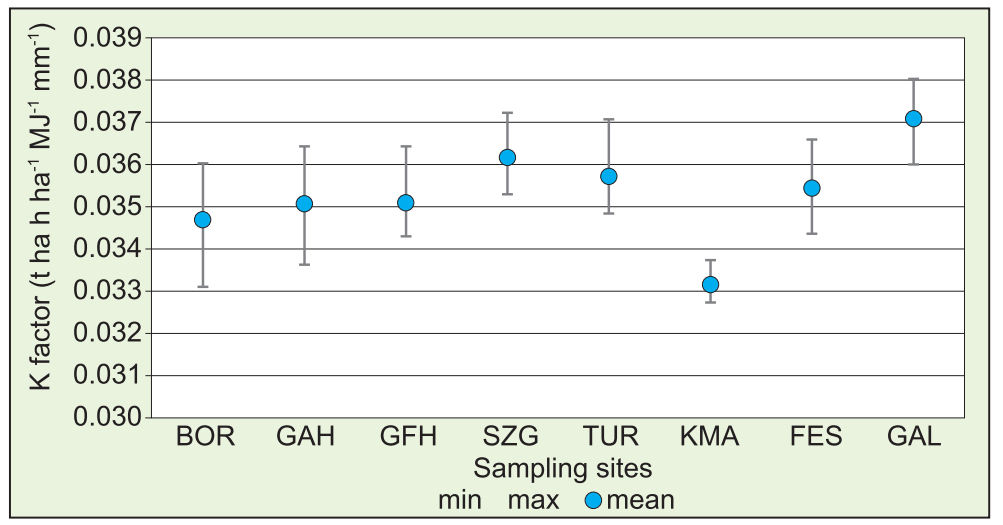

Fig. 2. Results of $K$ factor calculations with USLE methodology including all 3 applied methods (laser, pipette and aerometer) 
The calculated $K$ factors (Figure 2) were used to calculate the amount of soil loss with the USLE model. The results of these calculations are in Table 2.

Based on the maximum and minimum values of soil loss calculations, the difference between these two values have been expressed in Table 3 below. This Table shows the differences where the basis was the minimum value, so the percentage is expressing the difference of the maximum value compared to the minimum value (i.e. $6.1 \%$ means that the max. value is $6.1 \%$ higher than the min. value). The statistical ana-lyses proved that there were no differences in the measurements of the particle size distribution in case of KMA.

The differences between the amounts of soil loss calculated with the measured particle size classes resulted in very small $(0.4 \%)$ difference bet-ween the smallest and the greatest amount of soil loss. The high- est difference of the measured values was 6.1 percent, which can also be regarded as fairly low.

However, if we take into account the soil loss and not the percentage. We have to state that the amount of soil loss with the given parameterization is quite great, exceeding $70 \mathrm{t}^{-1} \mathrm{ha}^{-1} \mathrm{y}^{-1}$.

In the case, soil loss simulations on longer or steeper slopes, the difference between the smallest and the greatest amount of soil loss can grow to threefold. Therefore, this is a factor that must be considered as a tremendous increase in the amount of soil loss.

\section{Conclusion}

The analyses of the effects of particle size measurements methods proved that there can be considerable differences among the calculated soil losses if we use different par-

Table 2. Amount of soil losses calculated with the different $K$ factors in using the results of the particle size distributions measured with different methods

\begin{tabular}{l|l|c|l|l|c}
\hline \multicolumn{1}{c|}{ Site code } & \multicolumn{1}{|c|}{ Values } & $\begin{array}{c}\text { Soil loss, } \mathrm{t}^{-1} \\
\mathrm{ha}^{-1} \mathrm{y}^{-1}\end{array}$ & \multicolumn{1}{|c|}{ Site code } & \multicolumn{1}{c}{ Values } & $\begin{array}{c}\text { Soil loss, } \mathrm{t}^{-1} \\
\mathrm{ha}^{-1} \mathrm{y}^{-1}\end{array}$ \\
\hline \multirow{3}{*}{ BOR } & Minimum & 76.2 & \multirow{2}{*}{ TUR } & Minimum & 80.2 \\
& Maximum & 81.0 & Maximum & 83.4 \\
& Mean & 78.9 & & Mean & 81.3 \\
\hline \multirow{3}{*}{ GAH } & Minimum & 77.4 & \multirow{2}{*}{ KMA } & Minimum & 75.4 \\
& Maximum & 81.9 & Maximum & 75.8 \\
& Mean & 79.8 & & Mean & 75.4 \\
\hline \multirow{3}{*}{ GFH } & Minimum & 78.9 & \multirow{2}{*}{ FES } & Minimum & 79.1 \\
& Maximum & 81.9 & Maximum & 82.2 \\
& Mean & 79.9 & & Mean & 80.6 \\
\hline \multirow{3}{*}{ SZG } & Minimum & 81.2 & \multirow{2}{*}{ GAL } & Minimum & 82.8 \\
& Maximum & 83.7 & Maximum & 85.5 \\
\hline
\end{tabular}

Table 3. Differences in the amount of soil losses calculated with the different $K$ factors by using the results of the particle size distributions measured with different methods

\begin{tabular}{c|c|c|c}
\hline Site code & Values $_{\max }$ vs.Values \\
min'
\end{tabular}


ticle size measurement methods to assess the soil erodibility factor and use these factors in the USLE model to calculate the amount of soil losses.

We therefore conclude that, the method of particle size measurement do have an effect on soil erodibility factors and thus, also on the amount of the calculated soil losses, regardless of the fact that in this study there were no analyses of significance on the soil erodibility and soil loss calculations.

\section{REFERENCES}

ÁNGYÁN, J. 2001. Az európai agrármodell, a magyar útkeresés és a környezetgazdálkodás (The European agrarian-model, Hungarian road finding and agri-environmental management). Budapest, Agroinform Kiadóház, 308 p.

Bádonyi, K., Madarász, B., Kertész, Á. and CsepinszKy, B. 2008. Talajmúvelési módok és a talajerózió kapcsolatának vizsgálata zalai mintaterületen (Study of the relationship between tillage methods and soil erosion on an experimental site in Zala County). Földrajzi Értesítő / Hungarian Geographical Bulletin 57. (1-2 ): 147-167.

BARczi, A. and Joó, K. 2009. The role of kurgans in the Palaeopedological and Palaeoecological reconstruction of the Hungarian Great Plain. Zeitschrift für Geomorphologie Supplementbaende 53. (1): 131-137.

Barczi, A., Golyeva, A.A. and Pető, Á. 2009. Palaeoenvironmental reconstruction of Hungarian kurgans on the basis of the examination of paleosoils and phytolith analysis. Quaternary International 193. (1-2): 49-60.

BuzÁs, I. 1993. A talajfizikai, vízgazdálkodási és ásványtani vizsgálata (Physical, hidrological and mineralogy analyses of soils). In Talaj-és agrokémiai vizsgálati módszerkönyv 1. Ed.: BuzÁs, I., Budapest, Inda 4231 Publishing, 37-42.

Centeri, Cs. 2002. A talajerodálhatóság terepi mérése és hatása a talajvédő vetésforgó kiválasztására (Measuring soil erodibility on the field and its effects on soil protecting crop rotation). Növénytermelés 51. (2): 211-222.

Centeri, Cs., АкÁc, A. and JакAв, G. 2012. Land Use Change and Soil Degradation in a Nature Protected Area of East-Central Europe. In Land Use: Planning, Regulations, and Environment. Eds.: Aubrecht, C., Sergio Freire, S. and Steinnocherpr, K. New York, NOVA Science Publisher, 211-241.

Centeri, Cs., Herczeg, E., Vona, M., Balázs, K. and Penksza, K. 2009. The effects of land-use change on plant-soil-erosion relations, Nyereg Hill, Hungary.
Journal of Plant Nutrition and Soil Science 172. (4): 586-592.

Centeri, Cs., Kristóf, D., Evelpidou, N., Vassilopoulos, A., Giotitsas, I. and Varvarigos, G. 2011. Soil erosion risk and sediment transport within Paros Island, Greece. In Soil Erosion: Causes, Processes and Effects. Ed.: Fournier, A.J., New York, NOVA Science Publisher, 219-234.

Fonseca, F., de Figueiredo, T. and Bompastor Ramos, M.A. 2012. Carbon storage in the Mediterranean upland shrub communities of Montesinho Natural Park, northeast of Portugal. Agroforestry Systems 86. (3): 463-475.

Giovannini, G., Vallejo, R., Lucchesi, S., Bautista, S., Ciompi, S. and Llovet, J. 2001. Effects of land use and eventual fire on soil erodibility in dry Mediterranean conditions. Forest Ecology and Management 147. (1): 15-23.

Heng, B.C.P., Sander, G.C., Armstrong, A., Quinton, J.N., Chandler, J.H. and ScotT, C.F. 2011. Modelling the dynamics of soil erosion and size-selective sediment transport over non-uniform topography in flume-scale experiments. Water Resources Research 47. 1-11.

Kertész, Á. 1993. Application of GIS methods in soil erosion modelling. Computers, Environment and Urban Systems 17. 233-238.

Kondrlová, E., IgAz, D., HoráK, J. and Halászová, K. 2013. Soil texture analysis by optical method laboratory experiment on sample preparation prior to analysis. In Water resources. Forest, marine and ocean ecosystems. Proceedings of the $13^{\text {th }}$ International Multidisciplinary Scientific Geoconference SGEM, Sofia, 677-683.

Madarász, B., Bádonyi, K., Csepinszky, B., Mika, J. and Kertész, Á. 2011. Conservation tillage for rational water management and soil conservation. Hungarian Geographical Bulletin 60. (2): 117-133.

Madarász, B., Jakab, G., Szalai, Z. and Juhos, K. 2012. Lézeres szemcseösszetétel elemzés néhány előkészítő eljárásának vizsgálata nagy szervesanyag-tartalmú talajokon (Examination of sample preparation methods for the laser grain size analysis of soils with high organic matter content). Agrokémia és Talajtan 61. 381-398.

Merino, A., Pérez-Batallón, P. and Macias, F. 2004. Responses of soil organic matter and greenhouse gas fluxes to soil management and land use changes in a humid temperate region of southern Europe. Soil Biology and Chemistry 36. (6): 917-925.

Mie, G. 1908. Beiträge zur Optik trüber Medien, speziell kolloidaler Metallösungen., Leipzig. Annalen der. Physik. 330. pp. 377-445. MSZ 14043/3: 1979. MSZ-08-0205-1978.

Peтó, Á. 2011. Hazai talajszelvények fitolit morfotípus-diverzitása (Morphotype diversity of phytoliths in Hungarian soil profiles). Agrokémia és Talajtan 60. (1): 45-64. 
Peтő, Á. 2013. Studying modern soil profiles of different landscape zones in Hungary: an attempt to establish a soil-phytolith identification key. Quaternary International 287. 149-161.

Pradhan, B., Chaudhari, A., Adinarayana, J. and BuchroithNeR, M.F. 2011. Soil erosion assessment and its correlation with landslide events using remote sensing data and GIS: a case study at Penang Island, Malaysia. Environmental Monitoring and Assessment 184. (2): 715-727.

Rojas, R., Velleux, M., Julien, P.Y. and Johnson, B.E. 2008. Grid scale effects on watershed soil erosion models. Journal of Hydrologic Engineering 13. 793-802.
Schwertmann, U., Vogl, W., Kainz, M., Auerswald, K. and Martin, M. 1987. Bodenerosion durch Wasser. Stuttgart, Ulmer, $64 \mathrm{p}$.

Su, Y.Z., ZHAO, H.L., ZHAO, W.Z. and ZHANG, T.H. 2004. Fractal features of soil particle size distribution and the implication for indicating desertification. Geoderma 122. (1): 43-49.

Szilassi, P., Jordan, G., van Rompaey, A. and Csillag, G. 2006. Impacts of historical land use changes on erosion and agricultural soil properties in the Kali Basin at Lake Balaton, Hungary. Catena 68. (3): 96-108. 


\title{
Changing Ethnic Patterns of the Carpatho-Pannonian Area from the Late $15^{\text {th }}$ until the Early $21^{\text {st }}$ Century
}

\author{
Edited by: KÁroly KOCSIS and PATriK TÁTRAI \\ Hungarian Academy of Sciences, Research Centre for Astronomy and Earth Sciences \\ Budapest, 2013.
}

This is a collection of maps that visually introduces the changing ethnic patterns of the ethnically, religiously, culturally unique and diverse Carpathian Basin and its neighbourhood, the Carpatho-Pannonian area.

The Hungarian and English volume consist of three structural units. On the main map, pie charts depict the ethnic structure of the settlements in proportion to the population based on census data et the millennium. In the supplementary maps, changes of the ethnic structure can be seen at nine dates (in 1495, 1784, 1880, 1910, 1930, 1941, 1960, 1990 and 2001). The third unit of the work is the accompanying text, which outlines the ethnic trends of the past five hundred years in the studied area.

The antecedent of this publication is the "series of ethnic maps" published by the Geographical Research Institute of the Hungarian Academy of Sciences from the middle of the 1990's, which displayed each of the regions of the Carpathian Basin (in order of publication: Transylvania, Slovakia, Transcarpathia, Pannonian Croatia, Vojvodina, Transmura Region, Burgenland, Hungary). This work represents, on the one

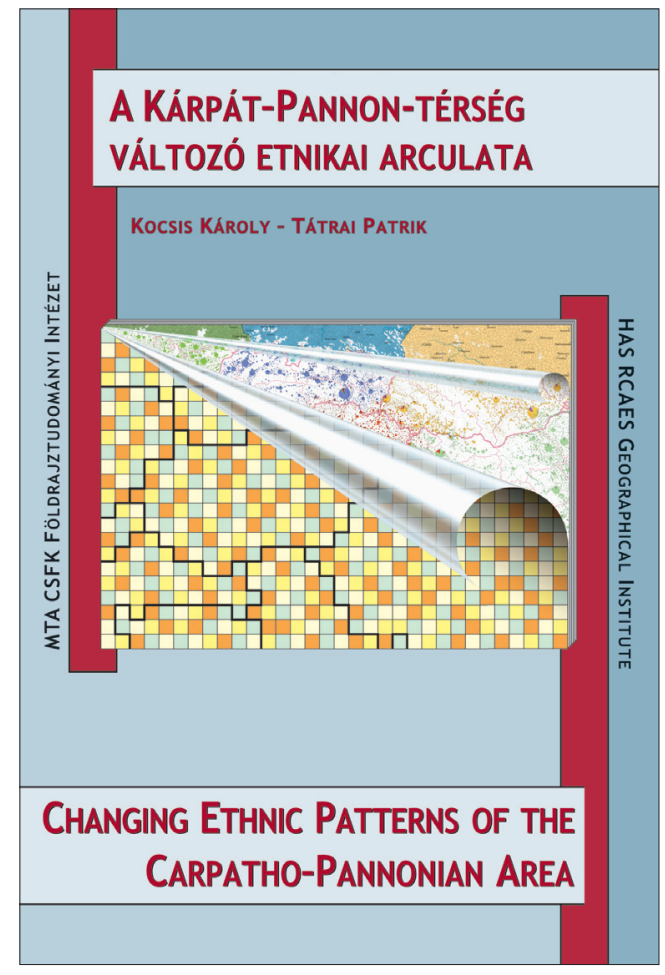
hand, the updated and revised version of these areas, and, on the other hand, regions beyond the Carpathian Basin not included on previous maps. Thus, the reader can browse ethnic data of some thirty thousand settlements in different maps.

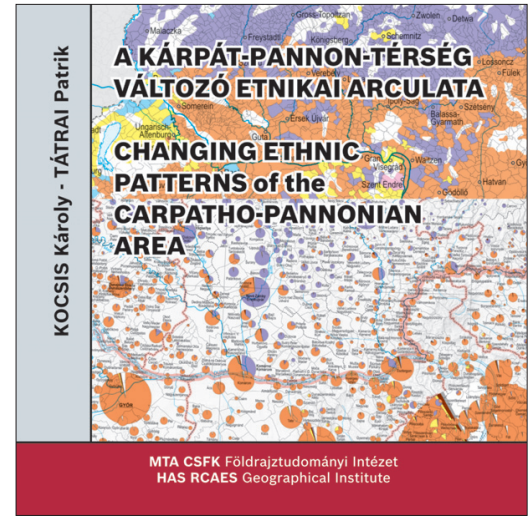

Price: EUR 12.00

Order: Geographical Institute RCAES HAS Library H-1112 Budapest, Budaörsi út 45.

E-mail: magyar.arpad@csfk.mta.hu 